\title{
Pemberdayaan Purna Tenaga Kerja Wanita melalui Pemanfaatan Pekarangan dan Pengolahan Jahe Menjadi Produk Bernilai Ekonomi
}

\section{Empowerment of the Former of Female Migrant Workers through Garden Utilization and Ginger Processing into Economic Value Products}

\author{
Mercy Bientri Yunindanova*, Mth. Sri Budiastuti, Trijono Djoko Sulistyo
}

Program Studi Agroteknologi, Fakultas Pertanian, Universitas Sebelas Maret (UNS), J1. Ir. Sutami 36A, Kentingan, Surakarta, Jawa Tengah, Indonesia

\begin{tabular}{l}
\hline Info Artikel \\
Diterima 12 Maret 2020 \\
Ditelaah 7 Mei 2020 \\
Disetujui 28 Juni 2020 \\
Tersedia daring 30 Juni 2020 \\
*Penulis untuk korespondensi \\
mercybientri fp@staff.uns.ac.id \\
\hline
\end{tabular}

Kata Kunci:

Herbal instan,

ketrampilan produktif,

wanita produktif

Keywords:

Herbal instant,

Productive skills,

Productive women

\begin{abstract}
ABSTRAK
Banyak wanita produktif di Desa Kadirejo, Kabupaten Semarang yang harus bekerja sebagai tenaga kerja wanita (TKW) di luar negeri. Meskipun pilihan ini menguntungkan secara ekonomi, di sisi lain hal ini memunculkan beberapa dampak negatif bagi keluarga dan masyarakat. Peran wanita sebagai istri dan ibu menjadi kurang optimal. Terlebih lagi, umumnya mereka kurang memiliki keterampilan ekonomi produktif saat kembali Indonesia setelah bekerja sebagai TKW. Kegiatan ini bertujuan untuk memberdayakan wanita purna TKW melalui pemanfaatan pekarangan dan pengolahan empon-empon khususnya jahe menjadi produk bernilai ekonomi. Kegiatan ini dilaksanakan di Desa Kadirejo, Kecamatan Pabelan, Kabupaten Semarang, Jawa Tengah sejak bulan Juli hingga September 2019. Program ini dilaksanakan melalui 6 tahap yaitu kajian masalah; sosialisasi mengenai potensi pekarangan dan informasi metode budidaya; praktek budidaya sayur dan pembagian benih; praktek pembuatan herbal instan; pelatihan pengemasan dan pelabelan; dan pelatihan marketing mix. Kegiatan ini secara nyata mampu memberikan keterampilan bagi wanita purna TKW. Para peserta telah menghasilkan produk herbal instan dengan kemasan yang siap jual. Selain itu, kelompok wanita juga telah memiliki kemampuan mengelola pekarangan. Harapan selanjutnya adalah peserta dapat mengembangkan ini menjadi bisnis yang dapat membantu keuangan keluarga tanpa harus meninggalkan tanggung jawab utama sebagai istri dan ibu.
\end{abstract}

\section{ABSTRACT}

A number of the productive women in Desa Kadirejo of Kabupaten Semarang have to work as female migrant workers (FMWs) who working abroad. Although this choice is economically profitable, these conditions also emerge several negative impacts on the family and society. Woman role as a wife and a mother becomes less optimal. Moreover, having finished as FMW, generally, most of the women were lack of productive skills. Thus, this program aimed to empower the former of FMWs through the optimization of home gardens and ginger processing to become economic value products. This activity was conducted in Desa Kadirejo, Kabupaten Semarang, Jawa Tengah, from July to September 2019. The steps of the activity were the problem and potential observation; socialization about the potential of home garden and cultivation method; vegetable cultivation practices and providing vegetable seeds; processing instant herbal from ginger; packaging and labeling training; and training of marketing mix. This activity was significantly able to provide life skills for the former of FMWs. The participants produced the ginger instants product, which was readily sold. Also, the former of FMWs had a skill for managing the home garden. In conclusion, by utilizing local resources, the former FMWs will be able to develop a business tant could support family finances without leaving the promary responsibility as wife and mother. 


\section{PENDAHULUAN}

Desa Kadirejo merupakan salah satu desa di Kecamatan Pabelan, Kabupaten Semarang, Jawa Tengah dengan mayoritas mata pencaharian sebagai petani. Tingkat ekonomi masyarakat yang tergolong rendah mendorong kelompok wanita produktif di Desa Kadirejo berusaha membantu perekonomian keluarga dengan menjadi tenaga kerja wanita (TKW) yang bekerja di luar negeri. Mereka bekerja sebagai asisten rumah tangga atau pada industri di luar negeri. Sistem kerja yang dilaksanakan oleh para TKW adalah kontrak dengan durasi lebih dari 1 tahun. Sebagian besar kelompok wanita produktif di desa tersebut memperpanjang kontrak hingga lebih dari 1 periode kontrak kerja karena pendapatan yang diperoleh sebagai TKW dinilai baik.

Status wanita produktif yang menjadi TKW pada rentang usia 18-56 tahun (Sari, 2017), baik wanita belum menikah maupun sudah menikah, secara ekonomi menguntungkan karena berkontribusi menambah pendapatan keluarga dan berperan dalam menambah devisa negara (Sugiono, Zakhra, \& Malia, 2017). Namun di sisi lain, terdapat hal negatif yang ditimbulkan yaitu pilihan pekerjaan menjadi TKW mengorbankan fungsi wanita sebagai istri dan ibu yang berperan penting dalam mendidik dan mendampingi tumbuh kembang anak-anaknya. Akibatnya bagi anak-anak para TKW adalah hilangnya sosok ibu bagi mereka. Sehingga anak-anak akan mencari figur lain atau anggota keluarga yang lain dalam proses sosialisasi dan internalisasi nilai-nilai keluarga dan masyarakat (Sutiana, Nandatia, A'yun, Prayogi, \& Imron, 2018). Figur tersebut dapat berupa ayah, tante atau nenek. Hal ini umumnya menghasilkan pola pengasuhan permisif (memanjakan) atau bahkan otoriter (Wahyuningsih, 2017). Selain itu, dampak lainnya adalah anak-anak dari ibu yang bekerja sebagai TKW tidak mendapatkan motivasi dan dorongan untuk belajar ketika para ibu lebih memilih bekerja sebagai TKW di luar negeri. Hal ini menjadi sangat ironis karena alasan menjadi TKW adalah untuk kepentingan pendidikan anak-anak (Kumalasari, Lestari, \& Irrenewaty, 2008). Peran istri yang tidak ada dalam keluarga untuk sementara waktu mengakibatkan ketidakseimbangan dalam keluarga.

Permasalahan lain yang dihadapi oleh kelompok wanita produktif di Desa Kadirejo adalah aktivitas setelah menjadi TKW. Wanita Purna TKW umumnya kembali ke Desa Kadirejo dengan alasan berakhirnya kontrak, dorongan keluarga atau faktor usia. Secara umum, mereka ingin tetap berkontribusi pada keuangan keluarga setelah kembali ke desa. Namun, karena ketrampilan yang didapatkan saat menjadi TKW hanya berupa ketrampilan domestik rumah tangga, mereka umumnya kesulitan untuk melakukan aktivitas produktif. Wanita purna TKW kurang memiliki pengetahuan dan ketrampilan produktif yang dapat mendukung keluarga. Wanita purna TKW bertahan hidup dengan beberapa strategi yaitu mendayagunakan aset tenaga kerja, aset modal manusia, aset keluarga, aset produktif, dan modal sosial (Adista, 2016). Wanita purna TKW juga tidak jarang tetap memiliki keinginan untuk kembali bekerja di luar negeri. Oleh karena itu, diperlukan metode atau strategi khusus sebagai upaya mengurangi jumlah wanita produktif kembali menjadi TKW (Tantriana, 2018).

Kegiatan pengabdian kepada masyarakat ini diharapkan dapat menjadi alternatif solusi atas beberapa masalah terkait wanita produktif yang berperan sebagai TKW dan wanita purna TKW. Kegiatan dengan sasaran utama wanita purna TKW dan Kelompok Wanita Tani (KWT) yang ada di Desa Kadirejo dilaksanakan dalam bentuk kegiatan pemberdayaan. Pemberdayaan masyarakat merupakan konsep pembanguan ekonomi yang bersifat people-centered dan participatory (Noor, 2011). Pemberdayaan dilakukan melalui pembinaan keahlian kerja dengan berfokus pada potensi lokal. Desa Kadirejo memiliki potensi sumber daya alam berupa pekarangan dan empon-empon. Pekarangan diharapkan dapat dioptimalkan menjadi sumber pangan dan gizi bagi keluarga. Hal ini sesuai pernyataan Nurwati, Lidar, \& Mufti (2015) bahwa pekarangan berkontribusi pada gizi keluarga sebagai penyedia kalori, protein, lemak, karbohidrat, kalium, phosphor, zat besi, vitamin A, vitamin B1 dan vitamin C. Sementara itu, empon-empon dapat diolah menjadi produk bernilai ekonomi berupa herbal instan. Dewasa ini herbal instan banyak diminati masyarakat karena khasiat dan rasanya yang menyegarkan (Pudiastutiningtyas, Mubin, Safitri, \& Kusumayanti, 2015). Herbal instan juga merupakan produk yang mudah dibuat dan disajikan oleh masyarakat (Permata dan Sayuti, 2016). Kegiatan ini bertujuan untuk memberdayakan wanita purna TKW melalui pemanfaatan pekarangan dan pengolahan emponempon khususnya jahe menjadi produk benilai ekonomi, untuk memberikan bekal ketrampilan (life skill) bagi wanita purna TKW dan untuk mengoptimalkan peran KWT dalam rangka pengurangan minat kelompok wanita produktif untuk menjadi TKW.

\section{METODE}

Kegiatan ini dilaksanakan di Desa Kadirejo, Kecamatan Pabelan, Kabupaten Seamarang, Jawa Tengah pada bulan Juli hingga September 2019. Peserta kegiatan berjumlah 30 orang yang terdiri atas wanita purna TKW dan anggota KWT di desa Kadirejo. Program ini dilaksanakan melalui 6 tahap. 
Tahap pertama adalah kajian masalah di lapangan. Pada tahap awal sebelum pelaksanaan kegiatan, tim pengabdi melakukan kegiatan survai lapangan untuk mengkaji kondisi mitra. Tim pengabdi sebelumnya melakukan beberapa kegiatan untuk mengidentifikasi potensi dan permasalahan yang ada. Kegiatan yang dilakukan meliputi survai lokasi dan wawancara untuk mendapatkan informasi mengenai potensi dan masalah mitra baik potensi sumber daya alam maupun potensi sumber daya manusia. Kegiatan survai dilakukan untuk berupaya menggali dan mengkomunikasikan solusi masalah yang ada bersama masyarakat mitra. Kajian masalah dan pengumpulan data dilakukan melalui (1) survai langsung ke lokasi desa untuk mengetahui potensi wilayah khususnya pekarangan, (2) pengamatan data penduduk dan (3) wawancara dengan perangkat desa, serta (4) wawancara kelompok wanita sasaran.

Tahap kedua adalah sosialisasi mengenai potensi pekarangan dan dilanjutkan tentang informasi metode budidaya. Sosialisasi dilakukan dengan pemberian materi oleh nara sumber dalam bidang pemanfaatan pekarangan dan pengolahan herbal instan. Selain pemberian materi, kegiatan dilanjutkan dengan bimbingan teknis budidaya tanaman. Bimbingan teknis diberikan dalam bentuk pembimbingan dan praktek langsung pembuatan jahe instan.

Tahap ketiga adalah pembagian benih dan bibit serta praktek budidaya sayur. Bibit sayuran yang diberikan berupa benih sayuran yang belum disemai dan juga bibit siap tanam. Benih yang diberikan berupa kangkung, sawi dan bayam. Sedangkan bibit yang siap tanam berupa selada, sawi dan cabai. Pemilihan 6 jenis bibit sayuran tersebut mempertimbangkan jenis sayuran yang biasa dikonsumsi warga masyarakat.

Tahap keempat adalah praktek pengolahan jahe menjadi herbal instan. Bahan yang digunakan adalah jahe emprit dan gula pasir. Sedangkan alat yang digunakan adalah kompor, wajan, blender, penyaring dan pisau. Tahap kelima adalah pelatihan pengemasan dan pelabelan. Tahap keenam adalah pelatihan marketing mix, pengemasan dan manajemen keuangan. Kelompok wanita sasaran diberikan sosialisasi dan bimbingan teknis.

Selain kegiatan pelatihan dan pembimbingan teknis, dilakukan juga kegiatan monitoring. Dilakukan upaya monitoring lahan demplot dan pekarangan untuk melihat aplikasi pelatihan yang telah dilaksanakan. Kegiatan pengambilan data dilakukan dengan pengamatan langsung, wawancara dan kuisioner terhadap kelompok sasaran. Parameter yang diamati diantaranya peningkatan pengetahuan dan ketrampilan dalam hal pengelolaan pekarangan, budidaya, pengolahan jahe instan, pengemasan, marketing mix, keberadaaan tanaman budidaya pada pekarangan, adanya produk jahe instan, serta adanya kemasan jahe instan. Pengambilan data dilakukan sebelum kegiatan dan pasca kegiatan.

\section{HASIL DAN PEMBAHASAN}

\section{Kajian Masalah di Lapangan}

Hasil survai awal memberikan gambaran bahwa terdapat 7 masalah dan potensi serta 7 alternatif solusi yang memungkinkan untuk dikerjakan bersama (Tabel 1). Adapun alternatif solusi yang ditawarkan mengutamakan pada keinginan mitra dan harapan mitra. Tim pengabdi berupaya memfasilitasi dengan mengintegrasikan ilmu pengetahuan dan teknologi (IPTEK) dan penerapan hasil penelitian di perguruan tinggi.

Tabel 1 Masalah dan potensi serta alternatif solusi kegiatan pengabdian masyrakat

\begin{tabular}{|c|c|c|}
\hline No & Masalah dan Potensi & Alternatif solusi \\
\hline 1 & Wanita produktif menjadi TKW & $\begin{array}{l}\text { Memberikan ketrampilan kerja berwirausaha untuk } \\
\text { membantu perekonomian keluarga }\end{array}$ \\
\hline 2 & $\begin{array}{l}\text { Wanita Purna TKW tidak memiliki aktivitas } \\
\text { ekonomi produktif }\end{array}$ & $\begin{array}{l}\text { Memberikan ketrampilan kerja berwirausaha untuk } \\
\text { membantu perekonomian keluarga }\end{array}$ \\
\hline 3 & $\begin{array}{l}\text { Pekarangan relatif luas namun belum } \\
\text { termanfaatkan }\end{array}$ & Pelatihan budidaya dan penyediaan bibit sayuran \\
\hline 4 & $\begin{array}{l}\text { Desa Kadirejo memiliki empon-empon namun } \\
\text { belum termanfaatkan }\end{array}$ & $\begin{array}{l}\text { Mengolah menjadi produk herbal instan (jahe dan } \\
\text { kunyit) }\end{array}$ \\
\hline 5 & Ketrampilan budidaya tanaman rendah & $\begin{array}{l}\text { Pembekalan teknik budidaya, penyiapan demplot } \\
\text { dan praktek budidaya tanaman secara langsung }\end{array}$ \\
\hline 6 & $\begin{array}{l}\text { Ketergantungan terhadap produk sayuran yang } \\
\text { harus dibeli dari luar }\end{array}$ & Membudidayakan sayuran sendiri di pekarangan \\
\hline 7 & $\begin{array}{l}\text { Kelompok wanita produktif belum mengetahui } \\
\text { prinsip marketing mix pada pemasaran produk }\end{array}$ & Pelatihan pengemasan, pelabelan, dan pemasaran. \\
\hline
\end{tabular}


Tabel 2 kondisi masyarakat pasca kegiatan

\begin{tabular}{|c|c|c|}
\hline No & Masalah dan Potensi & Pasca Kegiatan \\
\hline 1 & Wanita produktif menjadi TKW & $\begin{array}{l}\text { Anggota KWT memiliki ketrampilan dalam } \\
\text { pengelolaan pekarangan dan pembuatan herbal } \\
\text { instan dari Jahe }\end{array}$ \\
\hline 2 & $\begin{array}{l}\text { Wanita Purna TKW tidak memiliki aktivitas } \\
\text { ekonomi produktif }\end{array}$ & $\begin{array}{l}\text { Wanita purna TKW memiliki ketrampilan } \\
\text { pengelolaan pekarangan dan pembuatan jahe instan }\end{array}$ \\
\hline 3 & Pekarangan relatif luas namun belum termanfaatkan & $\begin{array}{l}\text { Pekarangan sudah mulai dimanfaatkan dengan } \\
\text { ditanami sayuran }\end{array}$ \\
\hline 4 & $\begin{array}{l}\text { Desa Kadirejo memiliki empon-empon namun belum } \\
\text { termanfaatkan }\end{array}$ & Masyarakat telah memiliki produk herbal instan Jahe \\
\hline 5 & Ketrampilan budidaya tanaman rendah & $\begin{array}{l}\text { Anggota KWT telah memiliki ketrampilan budidaya } \\
\text { sayuran }\end{array}$ \\
\hline 6 & $\begin{array}{l}\text { Ketergantungan terhadap produk sayuran yang harus } \\
\text { dibeli dari luar }\end{array}$ & $\begin{array}{l}\text { Anggota KWT telah membudidayakan sayuran di } \\
\text { pekarangan }\end{array}$ \\
\hline 7 & $\begin{array}{l}\text { Kelompok wanita produktif belum memiliki } \\
\text { pemahaman penuh tentang pengemasan dan } \\
\text { pelabelan }\end{array}$ & $\begin{array}{l}\text { Anggota KWT dan kelompok Wanita Purna TKW } \\
\text { telah memiliki pemahaman tentang pengemasan dan } \\
\text { pelabelan produk }\end{array}$ \\
\hline 8 & $\begin{array}{l}\text { Kelompok wanita produktif belum mengetahui } \\
\text { prinsip marketing mix pada pemasaran produk }\end{array}$ & $\begin{array}{l}\text { Anggota KWT dan kelompok Wanita Purna TKW } \\
\text { telah memiliki pemahaman tentang marketing mix }\end{array}$ \\
\hline
\end{tabular}

\section{Kondisi Masyarakat Pasca Kegiatan}

Informasi tentang perkembangan kemampuan masyarakat dan hasil yang dicapai diperoleh melalui kegiatan monitoring dan pengambilan data (Gambar 1). Kegiatan monitoring juga bertujuan untuk memberi apresiasi kepada KWT atau purna TKW yang telah berhasil menerapkan budidaya sayuran di lahan pekarangannya. Terdapat 3 peserta yang berhasil membudidayakan sayuran dengan baik. Ketiga peserta tersebut diberikan apresiasi berupa sertifikat dan bingkisan sebagai motivasi keberlanjutan kegiatan (Gambar 2). Selain monitoring lapang, dilakukan juga wawancara terhadap kelompok wanita produktif untuk mengetahui respon pasca kegiatan baik pekarangan maupun pembuatan herbal instan.

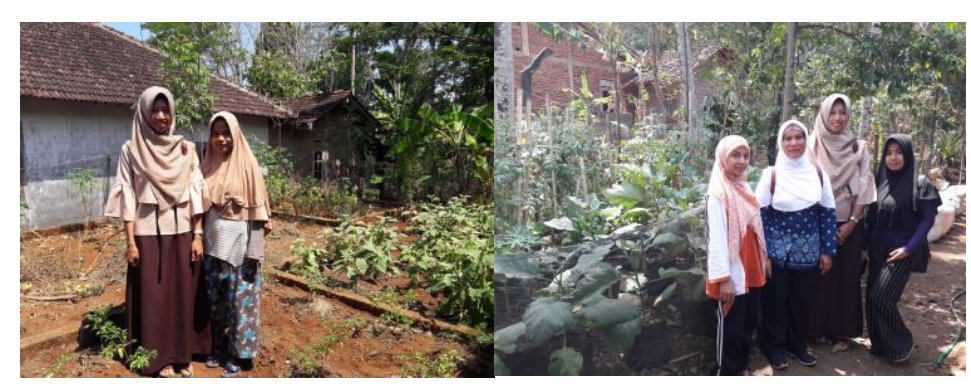

Gambar 1 Monitoring lahan pekarangan warga

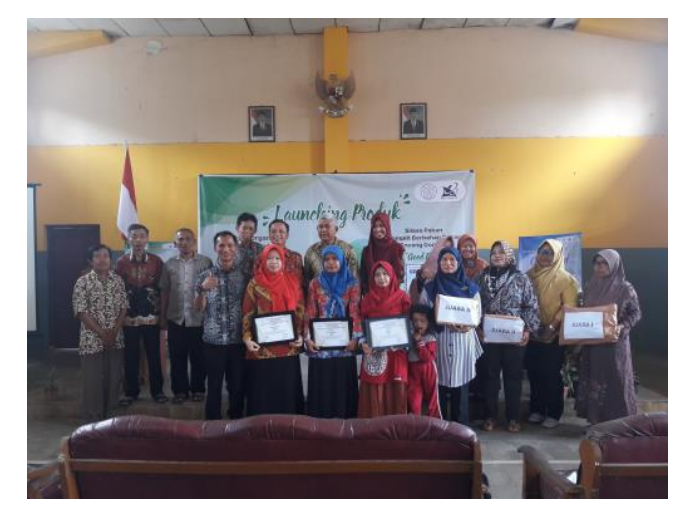

Gambar 2 Penyerahan sertifikat dan hadiah bagi pemenang lomba budidaya sayuran di pekarangan 
Hasil kegiatan pengabdian kepada masyarakat menunjukkan terjadinya peningkatan ketrampilan masyarakat yaitu ketrampilan budidaya dan pengolahan jahe instan. Selain itu, terjadinya optimalisasi penggunaan sumber daya pekarangan sehingga selain memiliki memiliki aktivitas produktif, kelompok wanita produktif dapat memenuhi kebutuhan domestik dari sayuran yang dibudidayakan di pekarangan. Pasca kegiatan ini, masyarakat memiliki produk layak pasar berupa herbal instan yang telah dibekali dengan kemasan dan label. Selain kemampuan menghasilkan produk, masyarakat memiliki pengetahuan tentang marketing mix untuk selanjutnya siap melakukan pemasaran produk (Tabel 2).

\section{Sosialisasi Pekarangan dan Budidaya Tanaman}

Pada tahap awal kegiatan pengabdian kepada masyarakat, dilakukan kegiatan pemaparan program dan sosialisasi pemanfaatan pekarangan. Pemaparan program ditujukan untuk menginformasikan keseluruhan agenda kegiatan kepada masayarakat. Sementara itu, kegiatan sosialisasi pemanfaatan pekarangan terdiri atas: 1) materi pekarangan dan potensinya dan 2) materi budidaya sayur secara mudah (Gambar 3). Kegiatan sosialisasi dibuka oleh Ketua Pengabdian Masyarakat (Mercy Bientri Y., S.P., M.Si) dan Kepala Desa Kadirejo. Peserta kegiatan ini adalah ibu-ibu purna TKW dan anggota kelompok wanita tani (KWT). Pemaparan tentang pekarangan ditujukan untuk memberikan informasi tentang potensi pekarangan sebagai sumber penopang kegiatan keluarga. Selain itu, kegiatan ini juga memberikan gambaran mengenai peran wanita yang dapat dioptimalkan dalam mengelola lahan di pekarangan. Masyarakat juga dikenalkan mengenai peran dan potensi pekarangan yang dapat menjadi sumber pangan sehat bagi keluarga. Pekarangan menyimpan potensi yang besar apabila dilakukan pengelolaan dengan baik. Nurwati, Lidar, dan Mufti (2015) menyatakan bahwa pada konsep Rumah Pangan Lestari (RPL), pekarangan memiliki potensi yang besar untuk mendukung pemenuhan kebutuhan pangan pada rumah tangga dan ketersediaan pangan apabila dilakukan pemanfaatan secara optimal. Pemanfaatan pekarangan akan dapat memenuhi kebutuhan domestik rumah tangga dengan penggunaan teknologi tepat guna yang bersifat sederhana (Sugiarso, Riyadi, \& Rusmadi, 2017).

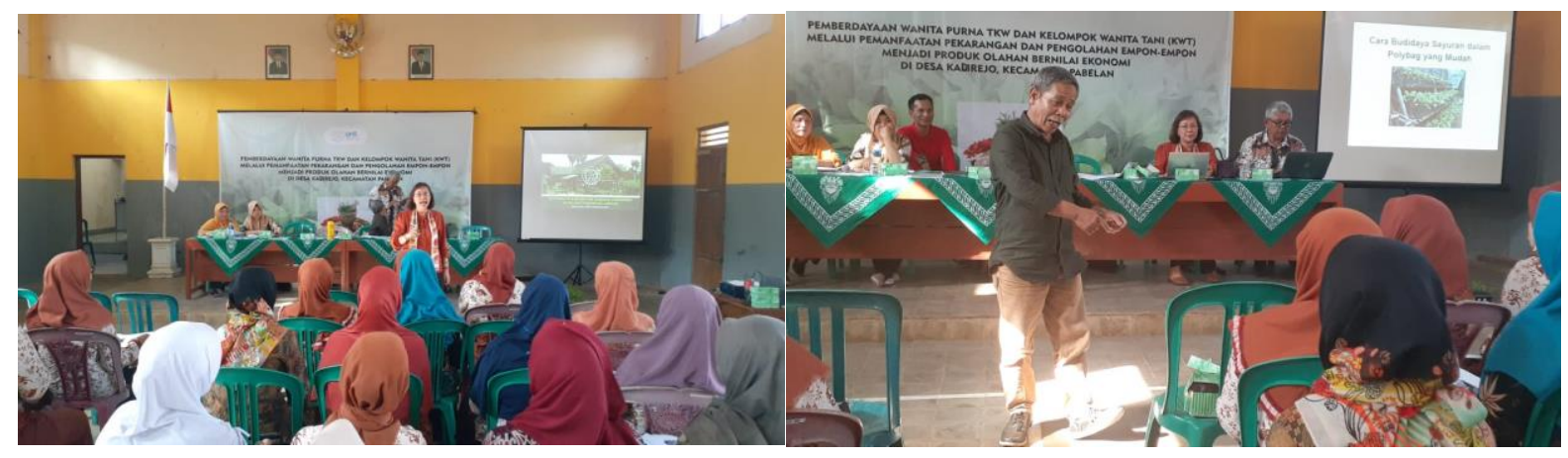

Gambar 3 Sosialisasi dan penyampaian materi

Setelah materi pekarangan, sosialisasi dilanjutkan dengan pemberian materi tentang budidaya tanaman sayuran secara mudah. Hal ini didasari pada kondisi saat ini bahwa mayoritas masyarakat enggan melakukan budidaya tanaman dikarenakan adanya anggapan bahwa kegiatan budidaya sayuran terlalu rumit. Pada kegiatan ini dijelaskan secara umum proses budiaya mulai dari pemilihan bibit, pembibitan, penanaman dan pemeliharaan tanaman hingga panen. Peserta sangat antusias mengikuti kegiatan ini terbukti dengan keterlibatan peserta dalam proses diskusi. Dari hasil diskusi terlihat beberapa peserta telah melakukan budidaya tanaman di pekarangan namun menemukan beberapa permasalahan. Sehingga kegiatan ini juga bermanfaat untuk pemberian informasi tentang masalah dalam budidaya sayuran. Jenis-jenis sayuran juga diperkenalkan kepada warga untuk mengetahui jenis sayuran yang memungkinkan dibudidayakan sendiri sehingga berkontribusi pada efisiensi ekonomi keluarga.

\section{Praktek Budidaya dan Pembagian Benih}

Setelah kegiatan penyampaian dasar-dasar budidaya tanaman hortikultura, kegiatan dilanjutkan dengan pembagian bibit dan benih sayuran. Bibit sayuran merupakan sarana produksi pertanian yang sangat penting dalam kegiatan budidaya. Penyediaan bibit unggul berkontribusi pada hasil yang baik. Ibu-ibu diberikan bibit sayuran untuk dipraktekan di lahan pekarangan. Harapan dari kegiatan pemberian bibit adalah untuk meningkatkan motivasi peserta serta menambah koleksi dalam pengelolaan lahan pekarangan rumah (Susanti dan Afrila, 2017). Jenis tanaman yang beragam di pekarangan nantinya juga berperan untuk menjaga keanekargamana hayati dan kualitas ekosistem (Irwan, Rogomulyo \& Trisnowati, 2018). Selain pemberian bantuan bibit, peserta juga diberikan bantuan alat budidaya (Gambar 4). 

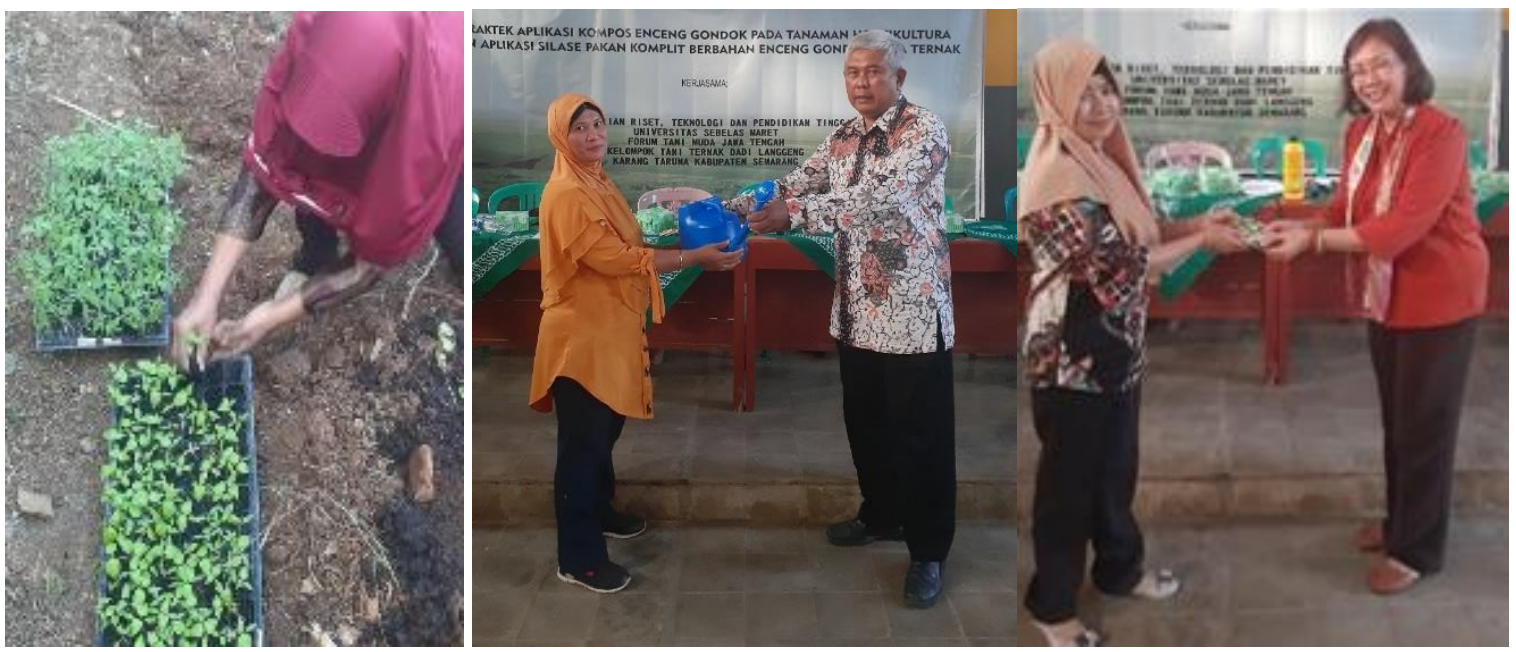

Gambar 4 Pembagian bibit, benih dan alat budidaya sayuran kepada perwakilan KWT dan wanita purna TKW

Setelah pembagian bibit, kegiatan dilanjutkan dengan praktek penanaman sayuran pada lahan demplot. Kegiatan dilakukan secara bersama-sama. Adapun tanaman yang dibudidayakan adalah selada. Kegiatan diawali dengan penjelasan tentang pembentukan bedengan dan persiapan lahan. Persiapan lahan diantaranya adalah aplikasi pupuk kompos sebagai pupuk dasar. Selanjutnya pelaksanaan budidaya yang meliputi tahapan pembuatan lubang tanam, pengaturan jarak tanam, pengambilan bibit dari tempat penyemaian (tray) dan teknik penanaman. Peserta juga diberikan kesempatan untuk menanam sayuran selada di lahan demplot. Setelah penanaman, peserta diberikan penjelasan mengenai teknik perawatan tanaman yang perlu dilakukan. Peserta terlihat sangat antusias mengikuti kegiatan praktek budiaya (Gambar 5).

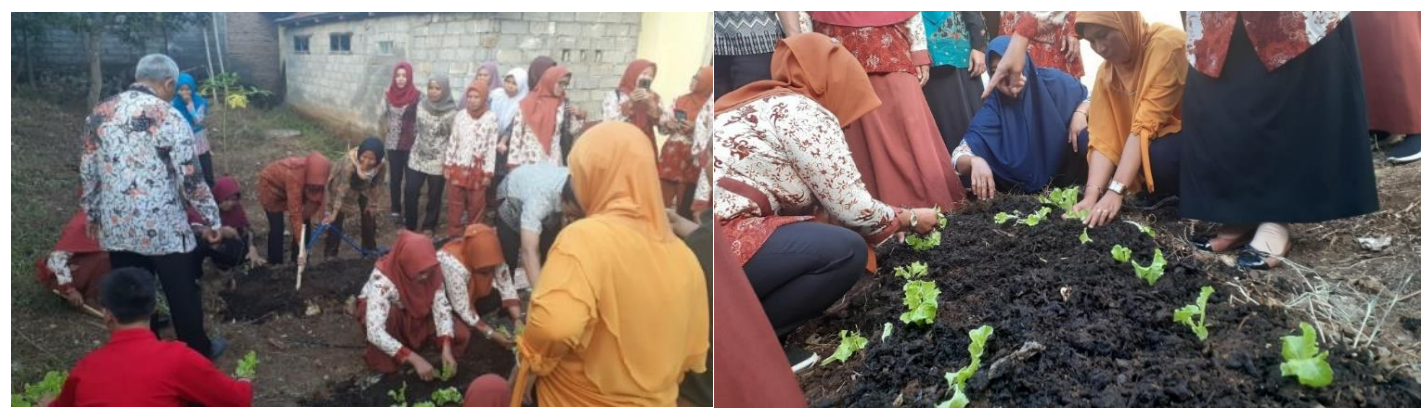

Gambar 5. Anggota KWT dan wanita pura TKW menyiapkan lahan budidaya dan menanam selada

\section{Praktek Pembuatan Herbal Instan}

Herbal instan merupakan minuman kesehatan berbahan dasar empon-empon dan masuk pada kategori pangan fungsional. Produk ini berbentuk granula atau serbuk yang terbuat dari bahan sari empon-empon dengan tambahan gula dan atau rempah-rempah tanpa bahan tambahan makanan (Pudiastutiningtyas, Mubin, Safitri, \& Kusumayanti, 2015). Proses pembuatan herbal instan dipilih sebagai program pelatihan ketrampilan wirausaha dikarenakan selain bahan dasar empon-empon yang menjadi potensi desa, produk ini juga dirasa mudah dalam proses pembuatannya. Selain itu, peralatan yang digunakan relatif sederhana dan rendah modal. Sehingga ideal untuk pengembangan UMKM (Usaha Mikro, Kecil dan Menengah).

Proses yang digunakan pada pembuatan herbal instan adalah metode kristalisasi. Jahe dipilih sebagai produk utama dikarenakan empon-empon ini lebih mudah di dapat. Selain itu, produk minuman jahe juga digemari banyak kalangan. Bahan minuman jahe menggunakan jahe emprit dikarenakan tingkat kepedasan lebih baik dibanding jahe gajah meskipun ukuran umbinya lebih kecil. Bahan tambahan yang digunakan adalah gula pasir dan air.

Pembuatan herbal instan jahe diawali dengan pencucian jahe emprit. Pencucian bertujuan untuk memperoleh bahan dasar yang bersih dan bebas kontaminasi. Selain merupakan ketrampilan dasar pembuatan produk, peserta juga diharapkan dapat memahami proses Cara Produksi Pangan yang Baik (CPPB) atau Good Manufacturing Practices (GMP). CPPB diaplikasikan pada industri yang memproduksi produk-produk untuk dikonsumsi seperti: produk obatobatan dan produk makanan. Diharapkan nantinya, hasil produk olahan industri rumah tangga ini dapat memperoleh 
Sertifikat Produksi Pangan Industri Rumah Tangga) (SPP-IRT), dimana salah satu persyaratannya adalah pelaksanaan CPPB (Suhardi, Kadita, \& Laksono, 2018).

Proses berikutnya adalah pengupasan kulit. Pengupasan kulit bertujuan untuk memperoleh produk yang bersih. Proses selanjutnya adalah pemotongan jahe menjadi ukuran yang lebih. Hal ini bertujuan untuk mempermudah proses menghaluskan (blender) jahe. Tahap berikutnya adalah menghaluskan jahe menggunakan blender dengan penambahan air. Dengan penggunaan bahan sebanyak $0.5 \mathrm{~kg}$, jumlah air yang ditambahkan adalah 0,5 liter. Kegiatan dilanjutkan dengan penyaringan sari jahe serta memisahkan patinya. Sari jahe dimasak dengan penambahan gula sebanyak 2 kali bobot jahe atau sesuai selera. Sari jahe dikristalkan dengan metode pemanasan menggunakan kompor. Pemasakan dilakukan dengan menggunakan api kecil dan pengadukan secara konsisten hingga air menyusut dan terbentuk kristal. Kuantitas produk yang dihasilkan ditentukan dari banyaknya gula yang ditambahkan (Gambar 6).

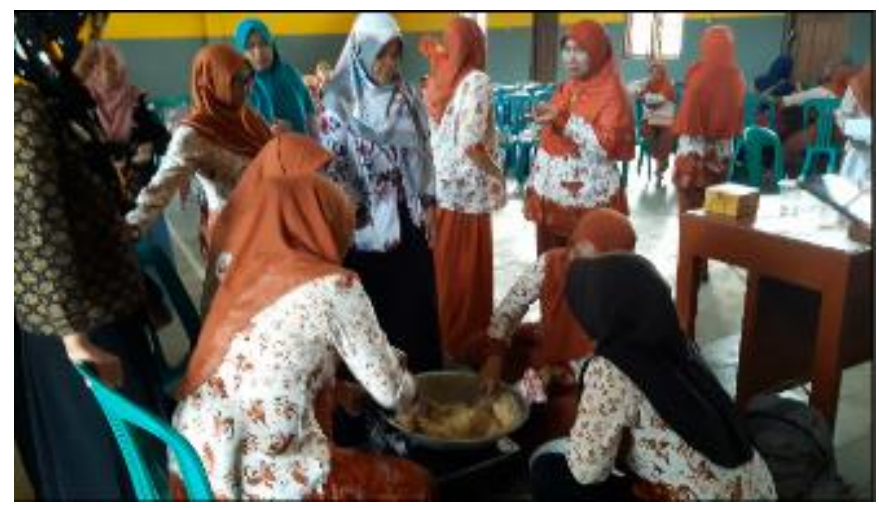

Gambar 6 Proses pembuatan herbal instan

\section{Pelatihan Pengemasan dan Pelabelan}

Kemasan merupakan bagian penting dari suatu produk. Selain fungsinya sebagai pelindung produk, saat ini kemasan juga berperan penting sebagai daya tarik suatu produk. Selama ini, pengetahuan tentang kemasan belum banyak diketahui oleh anggota KWT dan wanita purna TKW. Sehingga dalam mengemas produk, umumnya mereka masih sangat sederhana. Padahal, untuk meningkatkan nilai jual suatu produk UMKM, kemasan dan label adalah salah satu kunci (Nugrahani, 2015). Pada kegiatan pengabdian kali ini dikenalkan beberapa jenis kemasan yang memungkinkan digunakan untuk produk herbal instan. Setiap kemasan diberikan gambaran kelebihan dan kekurangan serta kemudahan dalam mendapatkannya. Anggota KWT dan kelompok wanita purna TKW sepakat menggunakan botol berbahan plastik-PP berukuran 250 gram (gambar 10).

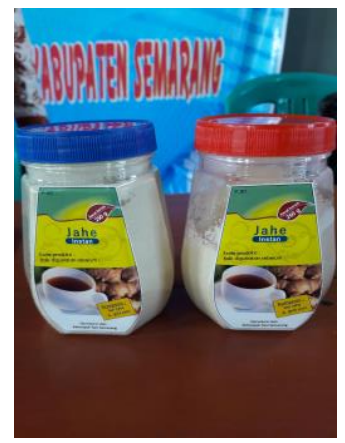

Gambar 7 Kemasan dan label produk untuk herbal instan jahe

Pada kegiatan pelatihan ini juga dikenalkan fungsi label dan komponen yang harus tertera di label. Hal ini karena label merupakan komponen penting dalam suatu produk. Label adalah unsur identitas produk (Widodo, Octavia, \& Munib, 2016). Identitas produk menjadi sangat penting sebagai media untuk meyakinkan pembeli. Label juga berperan sebagai media informasi dan promosi produk. Label juga merupakan upaya memberikan edukasi bagi konsumen tentang suatu produk. Komponen yang harus tertera pada label diantaranya jenis produk, merek produk, komposisi, bobot produk, dan produsen. Selain itu, desain label juga harus dibuat semenarik mungkin. Unsur yang meliputi warna, teks, serta elemen visual merupakan elemen yang bersifat saling melengkapi dalam upaya membentuk persepsi pembeli terhadap suatu produk (Nugrahani, 2015). Pada kegiatan ini, tim pendamping telah menyiapkan label 
yang siap diterapkan kepada KWT dan kelompok wanita purna TKW. Sebagai tahap inisiasi, masyarakat dibekali label produk berupa stiker yang telah dilengkapi dengan informasi produk (Gambar 7).

\section{Pengenalan Konsep Marketing Mix}

Tujuan proses produksi suatu produk selain untuk kepentingan konsumsi pribadi adalah untuk dipasarkan. Sehingga konsep pemasaran menjadi hal yang harus dikuasai calon produsen. Pada kegiatan pengabdian kepada masyarakat ini, pembahasan konsep marketing mix disampaikan secara sederhana agar lebih mudah dimengerti anggota KWT dan kelompok wanita purna TKW. Peserta dikenalkan pada konsep 4P pada marketing mix yaitu Product, Price, Place dan Promotion (Gambar 8). Meskipun sebetulnya terdapat komponen lain dalam pembahasan marketing mix seperti People dan Process, namun kegiatan ini bertujuan untuk secara bertahap mengenalkan konsep yang tidak terlalu berat. Faktor-faktor yang meliputi produk, harga, tempat dan promosi terbukti secara simultan berpengaruh pada minat beli konsumen terhadap suatu produk (Silaningsih \& Utami, 2018). Peserta dikenalkan pada konsep marketing mix yang merupakan strategi pemasaran untuk mencapai target penjualan yang dilaksanakan secara terpadu. Strategi yang tepat dalam bidang pemasaran sangat diperlukan agar keberlanjutan usaha tetap terjaga (Harini \& Yulianeu, 2019).

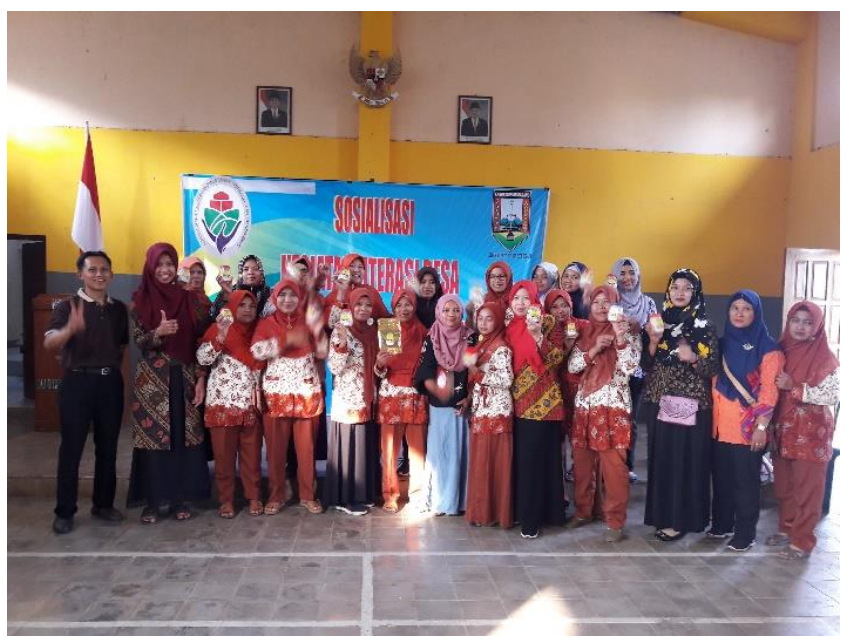

Gambar 8 Kegiatan pelatihan marketing mix

Pembahasan tentang Product menekankan pada kemampuan peserta untuk menggali kualitas dan keunikan produk untuk meningkatkan daya saing produk di pasaran. Pada konsep Price, peserta dikenalkan pada pemahaman bahwa produsen harus membuat konsumen merasa bahwa harga yang dia bayarkan sudah sesuai dengan kualitas produk yang dia dapatkan. Konsep Place menginformasikan kepada peserta terkait saluran distribusi atau tempat dimana konsumen dapat dengan mudah memperoleh produk tersebut. Pada konsep Promotion, peserta dikenalkan pada konsep mengajak konsumen agar menggunakan produk yang telah dibuat. Secara umum peserta sangat antusias mengikuti kegiatan pelatihan ini terlihat dari proses diskusi yang terjadi. Selama ini pembahasan marketing mix sangat jarang diketahui oleh masyarakat desa Kadirejo khususnya anggota KWT dan kelompok wanita purna TKW.

\section{Masalah yang Dihadapi}

Dalam kegiatan pengabdian kepada masyarakat ini dihadapi beberapa kendala. Namun kendala tersebut tidak berdampak signifikan terhadap pelaksanaan kegiatan. Kendala pertama yang dihadapi adalah motivasi awal peserta. Pada awal kegiatan, umumnya peserta belum sepenuhnya termotivasi untuk bergabung dalam agenda awal. Hal ini dikarenakan koordinasi tim pengabdi umumnya langsung pada ketua KWT, Ketua PKK dan Kepala Desa, sehingga sangat wajar apabila belum seluruh anggota faham akan rencana kegiatan. Kendala kedua yang dihadapi adalah membangun konsistensi kegiatan. Anggota KWT dan wanita purna TKW memiliki agenda domestik yang tidak dapat dihindari seperti kepentingan rumah tangga dan mengurus anak. Sehingga terkadang beberapa anggota tidak hadir dikarenakan urusan tersebut. Kendala ketiga adalah kurangnya rasa percaya diri peserta. Mayoritas peserta anggota KWT masih kurang percaya diri dengan kemampuannya untuk mempromosikan produk. Hal ini diatasi dengan menggali potensi dan peningkatan motivasi bahwa semua dapat dipelajari bersama. Untuk mengatasi kendala-kendala tersebut, tim pengabdi berupaya secara periodik melakukan monitoring untuk menjaga konsistensi pelaksanaan program, memastikan pemeliharaan tanaman berjalan baik sehingga motivasi peserta tetap tinggi hingga akhir program dan kegiatan menjadi berkelanjutan meskipun tanpa pendampingan tim pengabdi. 


\section{KESIMPULAN}

Program pemberdayaan ini telah menjadikan wanita purna TKW memiliki ketrampilan pengelolaan pekarangan dan pembuatan jahe instan. Kegiatan ini dapat menjadi cikal bakal bisnis yang dapat membentu keuangan keluarga tanpa harus meninggalkan tanggung jawab utama sebagai istri dan ibu. Ketrampilan ini diharapkan dapat menjadi bekal untuk pengolahan jenis empon-empon lainnya untuk diversifikasi produk di masa mendatang.

\section{DAFTAR PUSTAKA}

Adista, N. P. (2016). Srategi bertahan hidup mantan tenaga kerja perempuan (studi di desa sukorejo kecamatan pardasuka kabupaten pringsewu). Skripsi. Fakultas Ilmu Sosial dan Ilmu Politik Universitas Lampung Bandar Lampung.

Harini, C., Yulianeu. (2019). Meningkatkan kinerja pemasaran UMKM kota Semarang melalui strategi penetrasi pasar. Ikraith-Ekonomika, 2(1), 59-66.

Irwan, S. N. R., Rogomulyo, R., dan Trisnowati, S. (2018). Pemanfaatan Pekarangan Melalui Pengembangan Lanskap Produktif di Desa Mangunan, Kabupaten Bantul Yogyakarta. Jurnal Ilmu Pertanian Indonesia (JIPI), 23 (2), 148-157.

Kumalasari, D., Lestari, P. dan Irrenewaty, T. (2008). TKW dan pengaruhnya terhadap kelangsungan hidup berkeluarga dan kelangsungan pendidikan anak di kabupaten Sleman. Fakultas Ilmu Sosial dan Ekonomi Universitas Negeri Yogyakarta.

Noor, M. (2011). Pemberdayaan masyarakat. Jurnal Ilmiah CIVIS, 1(2), 87-99.

Nugrahani, R. (2015). Peran desain grafis pada label dan kemasan produk makanan UMKM. Imajinasi, 9(2), $127-136$.

Nurwati, N., Lidar, S., dan Mufti. (2015). Model pemberdayaan pekarangan di kecamatan Rumbai pesisir kota Pekanbaru. Jurnal Agribisnis, 17(1), 1-10.

Permata, D. A., dan Sayuti, K. (2016). Pembuatan minuman serbuk instan dari berbagai bagian tanaman meniran (Phyllanthus niruri). Jurnal Teknologi Pertanian Andalas, 20(1), 44-49. https://doi.org/10.25077/jtpa.20.1.4449.2016

Pudiastutiningtyas, N., Mubin, N., Safitri, L. I., Kusumayanti, H. (2015). Diversifikasi kunyit (Curcuma domestica) dan kencur (Kaempferia galanga 1.) sebagai minuman herbal serbuk siap saji. Metana, 11(01), 13- 20. https://doi.org/10.14710/metana.v11i01.12577

Silaningsih, E., Utami, P. (2018). Pengaruh marketing mix terhadap minat beli konsumen pada usaha mikro kecil dan menengah (UMKM) produk olahan makanan ringan. Jurnal Sosial Humaniora, 9(2): 144-158.

Sari, D.P. (2017). Analisis peran tenaga kerja wanita di luar negeri dalam meningkatkan pendapatan keluarga menurut perspektif ekonomi islam. Skripsi. Fakultas Ekonomi dan Bisnis Islam Universitas Islam Negeri (UIN), Raden Intan Lampung

Sugiarso, Riyadi, A., Rusmadi. (2017). Pemberdayaan masyarakat melalui pemanfaatan tanah pekarangan (PTP) untuk konservasi dan wirausaha agribisnis di kelurahan Kedung pane kota Semarang. DIMAS, 17(2), 343-366. http://dx.doi.org/10.21580/dms.2017.172.2433

Sugiono, A., Zakhra, A., Malia, E. (2017). Interpretasi dampak keuangan keluarga tenaga kerja wanita (studi fenomenologi TKW Pamekasan yang berimigrasi ke Saudi Arabia dan Malaysia). Akuntabel, Jurnal Akuntansi dan Keuangan, 14(2), 07-121.

Suhardi, B., Kadita, M., Laksono, P. W. (2018). Perbaikan proses produksi dengan standar cara produksi pangan yang baik (CPPB) dan work improvement in small enterprise (WISE) pada industri kerupuk Sala. Simetris, 9 (1), 579-586.

Susanti, S., Afrila, A. (2017). Pemberdayaan lahan pekarangan untuk budidaya tanaman organik di Prodosumbul desa Klampok kecamatan Singosari kabupaten Malang. Jurnal Akses Pengabdian Indonesia, 1(1), 18 - 33.

Sutiana, M. A., Nandatia, R. P., A’yun, Q., Prayogi, A. R. dan Imron, A. (2018). Pola pengasuhan anak pada keluarga TKW di kecamatan Srengat kabupaten Blitar. Paradigma, 06(01), 1-6.

Tantriana, D. (2018). Pemberdayaan wanita mantan TKW melalui pendampingan usaha di kabupaten Blitar (strategi pengurangan arus balik TKW ke luar negeri). Proceedings of Annual Conference on Community Engagement, 75-85. Retrieved from http://proceedings.uinsby.ac.id/index.php/ACCE/article/view/39

Wahyuningsih, S. (2017). Pola asuh anak keluarga tenaga kerja wanita (TKW) di desa Arjowilangun kecamatan 
Mercy Bientri Yunindanova et al. Abdihaz: Jurnal Pengabdian pada Masyarakat. 2(1):1-10

Kalipare kabupaten Malang. Kajian Moral dan Kewarganegaraan. 5(03), 784-799.

Widodo, A. S., Octavia, E. R., Munib, J. A. (2016). Teknik perancangan label dan kemasan produk tekstil konveksi bagi siswa SMK di Surakarta. Proceeding Seminar Nasional Peningkatan Kapabilitas UMKM dalam Mewujudkan UMKM Naik Kelas, 386-394. 